\title{
Beata Papuda-Dolińska
}

Uniwersytet Marii Curie-Skłodowskiej w Lublinie

\section{TRUDNOŚCI WYCHOWAWCZE W PRZYPADKU UCZNIÓW Z NIEPEŁNOSPRAWNOŚCIĄ WZROKU W SZKOŁACH OGÓLNODOSTĘPNYCH, INTEGRACYJNYCH I SPECJALNYCH}

\begin{abstract}
Streszczenie: W artykule opisano trudności wychowawcze dotyczące uczniów z niepełnosprawnością wzroku z perspektywy pracujących z nimi nauczycieli w szkołach ogólnodostępnych, integracyjnych i specjalnych. W części teoretycznej poruszono aktualne problemy z kategorii wychowania w pedagogice specjalnej oraz przywołano potwierdzone badaniami zachowania problemowe uczniów niewidomych i słabowidzących. Część empiryczna to analiza wypowiedzi nauczycieli na temat trudności wychowawczych uczniów z niepełnosprawnością wzroku, które zostały skategoryzowane według typologii Norberta Haversa. W ostatniej części podjęto próbę wyjaśnienia częstszego występowania trudności wychowawczych wśród omawianej grupy uczniów w szkołach ogólnodostępnych i integracyjnych w porównaniu do dzieci ze szkół specjalnych. Wyróżniono trzy płaszczyzny eksplikatywne: brak równowagi między adaptacją a emancypacją w procesie wychowania, instrumentalizm rewalidacyjny, endo- i egzogenne uwarunkowania trudności wychowawczych.
\end{abstract}

Słowa kluczowe: trudności wychowawcze, niepełnosprawność wzroku, integracja, edukacja włączająca

\section{O POTRZEBIE BADAŃ NAD KATEGORIĄ WYCHOWANIA W PEDAGOGICE SPECJALNEJ}

W polskim systemie edukacji szkoła traktowana jest nie tylko jako instytucja oświatowa, ale także wychowawcza, dlatego odgrywa istotną rolę w przygotowaniu uczniów do pełnego uczestnictwa w życiu społecznym. Cele i priorytety stricte 
wychowawcze określane i opisywane są w tekstach kluczowych dokumentów, takich jak ustawa o systemie oświaty czy podstawa programowa. Według tych zapisów w procesie kształcenia ogólnego szkoła podstawowa ma za zadanie wytworzyć u uczniów postawy sprzyjające ich dalszemu rozwojowi indywidualnemu i społecznemu, takie jak: uczciwość, wiarygodność, odpowiedzialność, wytrwałość, poczucie własnej wartości, szacunek dla innych ludzi, ciekawość poznawcza, kreatywność, przedsiębiorczość, kultura osobista, gotowość do uczestnictwa w kulturze, podejmowania inicjatyw oraz do pracy zespołowej (Rozporządzenie Ministerstwa Edukacji Narodowej z dnia 27 sierpnia 2012 r.). Co więc powoduje, że nie wszyscy uczniowie opuszczający mury szkoły są uczciwi, odpowiedzialni, wytrwali, kreatywni...? Refleksja nad problemem przynosi odpowiedzi truistyczne. Albo oddziaływania wychowawcze szkoły są zbyt słabe w porównaniu do innych, alternatywnych przekazów oferowanych przez pozostałe agendy socjalizacji, albo wychowanie w szkole jest tylko deklaracją planów i zamierzeń niemających za wiele wspólnego z codziennością szkolną. Postawienie celów wychowawczych jako punkt startowy, skonstruowanie ich wskaźników w postaci „sylwetki absolwenta” - efektu końcowego nie gwarantują, że najtrudniejszym, bo zależnym od samego wychowanka, jego rodziny oraz splotu innych oddziaływań socjalizacyjnych, etapem „pomiędzy" uda się wedle tych ustaleń sterować. Trzecia opcja przez połączenie dwóch poprzednich prowadzić może do wielopostaciowego i wieloaspektowego zjawiska, jakim jest kryzys wychowania.

Kryzys wychowania jako nośne hasło współczesnych refleksji nad losem młodego pokolenia jest nie tylko uniwersalną odpowiedzią malkontentów na wszelkiego typu problemy pedagogiczne, ale także synonimem rzeczywistej deprecjacji celów i priorytetów wychowawczych, których miejsce zajmują mierzalne efekty dydaktyczne (Chłodna 2008). Przejawów owego kryzysu jest jednak więcej: upadek autorytetu nauczyciela, monopolizacja wiedzy, instrumentalizm dydaktyczny, alternatywne i sprzeczne z przekazem szkoły wpływy (anty)wychowawcze mediów, grup rówieśniczych, rodziny. Tym, co istotne dla niniejszych rozważań, jest podkreślenie, że wymienione problemy są również aktualne w szkolnictwie specjalnym, a tym bardziej integracyjnym (Krause 2011, s. 87). Mimo tego nadal zdają się być marginalizowane zarówno w opracowaniach z zakresu pedagogiki specjalnej, jak i w praktyce nauczycielskiej. W badaniach fokusowych Zenona Gajdzicy (2013) z udziałem nauczycieli wśród sukcesów edukacji integracyjnej nie pojawił się widoczny sukces wychowawczy, a szczegółowa analiza tytułów publikacji z zakresu pedagogiki specjalnej dokonana przez tego autora pokazuje, że wątek jest podejmowany stosunkowo rzadko (Gajdzica 2015). Oprócz tego dowodem zaniedbania kategorii wychowania w pedagogice specjalnej jest fakt, że aspekty wychowawcze stanowią mały procent treści w programach specjalności pedagogiki specjalnej (Krause 2011, s. 88). 
Jednocześnie wychowanie zajmuje silną pozycję w teleologii pedagogiki specjalnej. Wychowanie jawi się tu jako swoisty cel, czasem także jako narzędzie do osiągnięcia możliwie najpełniejszego włączania ludzi obarczonych niepełnosprawnością (i innymi zaburzeniami czy ponadprzeciętnymi zdolnościami) do społecznej przestrzeni życia codziennego. Wychowanie obok kształcenia, opieki i terapii stanowi przedmiot pedagogiki specjalnej (Sękowska 1985, s. 6; Dykcik 2001, s. 13). Wydaje się więc, że w pedagogice specjalnej uzewnętrzniają się podobne tendencje, co w pedagogice ogólnej - wychowanie jest istotnym celem oddziaływań na uczniów, teoretycznie równoważnym z procesami kształcenia i rehabilitacji, ale w praktyce zwykle ogranicza się do podporządkowania wychowanka wymogom społecznym. Wszelakie odchylenia, o ile są trwałe i nie poddają się standardowym działaniom wychowującym (dyscyplinującym?) nauczyciela, uważane są za trudności wychowawcze. Pozostaje pytanie: czy takie interpretacje są poprawne, jeśli mamy do czynienia $\mathrm{z}$ wychowankiem $\mathrm{z}$ niepełnosprawnością?

\section{O TRUDNOŚCIACH WYCHOWAWCZYCH W PRZYPADKU UCZNIÓW NIEWIDOMYCH I SŁABOWIDZĄCYCH}

Poparte doświadczeniem twierdzenie, że w placówkach z dziećmi z niepełnosprawnościami mniej jest sytuacji alarmujących, agresji, przestępczości, uzależnień może być traktowane jako usprawiedliwienie dla przesuwania na drugi plan kwestii wychowawczych; jednocześnie nie pokazuje ono pełni problemu, bowiem uczniowie z niepełnosprawnością kształcą się jeszcze w szkołach integracyjnych i ogólnodostępnych (Krause 2011, s. 89). Jak pokazują statystyki, znacząco przybywa uczniów niewidomych i słabowidzących korzystających z tych dwóch form edukacji (Oświata $i$ wychowanie $w$ roku szkolnym... 2014). Wspólne uczenie się z pełnosprawnymi rówieśnikami, specyfika funkcjonowania ucznia słabowidzącego i niewidomego oraz konieczność dostosowania zajęć edukacyjnych implikować mogą pewne zachowania i reakcje uznawane przez nauczycieli za trudności wychowawcze. W literaturze pedagogicznej definiowane są one jako zachowania dzieci, które są niezgodne z przyjętymi normami życia społecznego, równocześnie uporczywe i niepoddające się zwykłym zabiegom wychowawczym (Łobocki 1989, s. 12). Badania Zofii Palak (2000) sugerują, iż nie można mówić o występowaniu specyficznych zaburzeń zachowania u uczniów z niepełnosprawnościami wzroku w szkołach specjalnych czy nawet integracyjnych, ale o ewentualnej tendencji do sporadycznego ich ujawniania. Wśród uczniów ze szkół specjalnych pojawiły się epizody niedostosowanego zachowania. Jego przejawami były m.in.: gwałtowność, wybuchy gniewu, słowna agresja, ignorowanie przepisów i zwyczajów panujących w zbiorowości. Przyczyny takich różnic autorka upatruje w oddziaływaniu życia 
internatowego na realizację potrzeb ucznia, czyli swego rodzaju „deprywacji instytucjonalnej”, oraz w zwiększonej tolerancji na frustrację u uczniów ze szkół ogólnodostępnych. Z kolei w badaniach Danuty Osik (1991, s. 171) 66,7\% badanych nauczycieli szkół masowych kształcących dzieci niedowidzące nie zaobserwowało problemów wychowawczych. Natomiast żądanie pomocy i szczególnego postępowania ze strony kolegów i nauczycieli zauważa 30\% respondentów, w jednym przypadku (3,3\%) dostrzeżono izolowanie się ucznia od rówieśników i odrzucenie oferowanej mu pomocy. Trudności wychowawcze w postaci konfliktowości, agresji lub izolacji, zamykania się w sobie mogą być bezpośrednią konsekwencją niekorzystnej sytuacji społecznej wynikającej z odmienności czy też kontrowersyjności uczniów z niepełnosprawnością wzroku. W badaniach Kornelii Czerwińskiej (2007) dotyczących wiedzy uczniów w wieku wczesnoszkolnym na temat osób niewidomych prezentowane były głównie stereotypowe przekonania. Ponad 49\% respondentów przypisywała niewidomym negatywne atrybuty, a 43,7\% postrzegało osoby niewidome jako zależne i potrzebujące pomocy. W badaniach nad poczuciem jakości życia z chorobą zezową najniższe wyniki dotyczyły sfer „Przynależność do grupy”, „Integracja z grupą”, co może oznaczać, że stopień doświadczanej satysfakcji z relacji z innymi u tych dzieci jest niewystarczający (Oleś i in. 2002). Inną hipotetyczną przyczyną trudności wychowawczych wśród uczniów z niepełnosprawnością wzroku może być deprywacja potrzeb: narażenie na frustrację powoduje pojawianie się mechanizmów obronnych - zachowań odbieranych jako „dziecinne”, egocentryczne, nieadekwatne lub nieprzystosowawcze (Sękowska 1998, s. 129).

\section{BADANIA WŁASNE}

Przeprowadzone badania obejmowały 59 nauczycieli pracujących w szkołach ogólnodostępnych, integracyjnych i specjalnych, do których uczęszczają uczniowie z niepełnosprawnością wzroku. Analizowano sytuację 90 uczniów (w ramach każdej z form organizacyjnych kształcenia po 30 uczniów) pod kątem trudności wychowawczych. Wykorzystano metodę dialogową, rozmowę indywidualną z wychowawcą lub pedagogiem szkolnym na temat dziecka i jego zachowania.

Odpowiedzi badanych nauczycieli pokazują, że 30\% dzieci z niepełnosprawnością wzroku sprawia odczuwalne dla nich trudności wychowawcze. Więcej nauczycieli pracujących w placówkach oferujących formy niesegregacyjne niż specjalnych dostrzega trudności wychowawcze u niewidomych lub słabowidzących podopiecznych. W szkołach integracyjnych trudności wychowawcze dotyczyły $37 \%$ dzieci z niepełnosprawnością wzroku. W szkołach ogólnodostępnych $33 \%$ z badanych uczniów sprawia problemy wychowawcze. Natomiast nauczyciele szkół i ośrodków specjalnych o tego typu problemach mówili w odniesieniu do $20 \%$ uczniów. 
Bazując na typologii trudności wychowawczych Norberta Haversa (1981, za: Siewecka 2009), udało się dopasować wypowiedzi nauczycieli do poszczególnych typów zaburzeń oraz utworzono kategorie dodatkowe, które mieściły problemy nieujęte w propozycji autora.

Nauczyciele szkół ogólnodostępnych, opisując dostrzeżone trudności wychowawcze podopiecznych z niepełnosprawnością wzroku, wymienili następujące problemy:

1. Zachowania agresywne (agresja fizyczna i werbalna) - „częste konflikty z kolegami, agresja słowna”, „uczeń prowokuje kłótnie, jest niegrzeczny wobec dzieci i lekko agresywny”, „konfliktowość i agresja”;

2. Zachowania powściągliwe (przesadna lękliwość i zamykanie się w sobie) - „niska motywacja do pracy, ogólna niechęć do działania, bierność”, „wycofywanie się, trudność w nawiązywaniu kontaktów, nieśmiałośc";

3. Zachowania niedojrzałe (nieadekwatne do danego okresu rozwojowego) - „problemy ze skupieniem uwagi”, „gadatliwość, nieumiejętność kontrolowania swoich emocji”, „często wypowiada się na temat inny niż klasa”, „silne reakcje emocjonalne nieadekwatne do sytuacji”, „podczas lekcji rozprasza się, wyłącza się, odpowiada niepytany, zgłasza się, gdy nie zna odpowiedzi";

4. Zachowania sprzeczne z obowiązkami ucznia - „niechęć do nauki, brak zdyscyplinowania”, „uczeń niesystematyczny, nieobowiązkowy, leniwy”, „częste spóźnienia”.

W szkołach integracyjnych trudności wychowawcze dotyczyły 37\% uczniów z niepełnosprawnością wzroku i mieściły się w następujących kategoriach:

1. Zachowania agresywne (agresja fizyczna i werbalna) - „skarży, krzyczy na dzieci";

2. Zachowania powściągliwe (przesadna lękliwość i zamykanie się w sobie) - „silne rekcje emocjonalne, lękliwość”, „nadwrażliwa, wycofuje się w sytuacji niepowodzen”, „bierność, wycofanie, ograniczony kontakt z rówieśnikami";

3. Zachowania niedojrzałe (nieadekwatne do danego okresu rozwojowego) - „nie wywiązuje się z umów, buntuje się, zmienność nastrojów”, "nadpobudliwy, rozgadany”, „niesamodzielny, wymaga stałej kontroli, oczekujący pomocy”, "trudności w przewidywaniu konsekwencji, nie radzi sobie z podstawowymi zadaniami, podatny na wpływ kolegów", „ruchliwy, chaotyczny, mało uporządkowany”;

4. Zachowania sprzeczne z obowiązkami ucznia - „niezdyscyplinowana, spóźnia się na zajęcia, rozmawia na lekcjach”, „trudności w uczeniu się, słaba motywacja”. 
Wychowawcy szkół specjalnych o trudnościach wychowawczych podopiecznych mówili najrzadziej. Dotyczyły one jedynie $20 \%$ uczniów. Wymienione problemy udało się dopasować do wyróżnionych kategorii zachowań:

1. Zachowania agresywne (agresja fizyczna i werbalna) - „buntuje się, agresywny";

2. Zachowania powściągliwe (przesadna lękliwość i zamykanie się w sobie) - „nieśmiałość, bierność, mała aktywność”;

3. Zachowania niedojrzałe (nieadekwatne do danego okresu rozwojowego) - „nie radzi sobie z emocjami, silne reakcje na frustracje”, „infantylne zachowania, zaburzona równowaga psychiczna”;

4. Zachowania sprzeczne z obowiązkami ucznia - „bardzo wolne tempo pracy, niechęć, niska motywacja”, „zdarza się uciec z lekcji, przeszkadza, wagaruje, nieodpowiednio odzywa się do nauczycieli".

Jak już zostało zaznaczone, problemy te dotyczyły niewielkiej ilości dzieci kształconych w szkołach specjalnych. Nazbyt śmiałe i przypuszczalnie nieprawdziwe byłoby twierdzenie, że do tych szkół uczęszczają uczniowie „grzeczni”, bardziej dojrzali czy przystosowani do funkcjonowania w szkole. Być może każdy z tych uczniów, gdyby znalazł się w warunkach szkoły ogólnodostępnej czy integracyjnej, zostałby oceniony jako sprawiający mniejsze lub większe trudności wychowawcze. Tym samym trudności wychowawcze można uznać za pojęcie relatywne, które w zależności od obiektywnych zachowań uczniów, indywidualnej tolerancji nauczyciela, a także warunków edukacji i modelu kształcenia może mieć inne znaczenie.

\section{PŁASZCZYZNY EKSPLIKATYWNE}

Wyjaśnień różnego stopnia odczuwanego natężenia trudności wychowawczych w zależności od formy organizacyjnej kształcenia można poszukiwać na gruncie aktualnych trendów w rozważaniach na temat wychowania w pedagogice specjalnej. Trudności wychowawcze jako zjawisko częstsze w szkołach ogólnodostępnych i integracyjnych w porównaniu do szkół specjalnych może mieć źródło w źle pojętej normalizacji związanej z dominacją autorytetu pełnosprawności nad niepełnosprawnością (Krause 2011, s. 88). Oznacza ona spełnianie oczekiwań wychowawczych dominującej grupy osób pełnosprawnych, która to wyznacza normy zachowania się np. w szkole. Różnego rodzaju zabiegi wychowawcze, a także rehabilitacyjne, stanowią instrumentarium nauczyciela służące do jak najskuteczniejszego przystosowania ucznia z niepełnosprawnością do wspomnianych norm. W takim kontekście trudności wychowawcze należałoby definiować jako zachowania inne, nietypowe, odmienne od normy ustalanej przez pełnosprawną większość, a do takich zaliczają się również reakcje ucznia wynikające bezpośrednio z jego dysfunkcji. 
Jak pisze Tadeusz Majewski (1983, s. 132), dzieci niewidome częściej przejawiają emocje o negatywnym zabarwieniu. Ich źródłem są tzw. sytuacje trudne, zwane też stresowymi, w jakich dziecko niewidome znajduje się częściej niż jego widzący rówieśnik. Notoryczne pojawianie się opisywanych zachowań może być odczytywane jako problemy behawioralne. Ich występowanie nie tylko utrudnia dydaktycznie rozumiany proces uczenia się, ale także relacje z innymi dziećmi w klasie i wtórnie może być przyczyną niechęci rówieśników do tych dzieci. Uczeń niewidomy lub słabowidzący na skutek niepełnosprawności nie zawsze jest w stanie się do nich dopasować, np. nieproszony do odpowiedzi zadaje dużo pytań w celu uzupełnienia informacji wizualnych, których nie posiada; wykonuje gwałtowne lub powtarzalne ruchy - blindyzmy, tym samym sprawiając wrażenie nieskupionego itp. Z kolei w szkołach specjalnych normy wzajemnego współżycia $w$ klasie są budowane na podstawie typowych dla uczniów z niepełnosprawnością wzroku zachowaniach. Świadomość i wiedza pedagogów specjalnych na temat ich przyczyn podnosi granicę tolerancji na zachowania odmienne, dzięki czemu nie muszą być one automatycznie zaliczane do trudności wychowawczych. Być może uporczywość pewnych zachowań zadecydowała, że nauczyciele uznali je za trudności wychowawcze, które w swej istocie nie musiały mieć bezpośredniego związku z niepełnosprawnością wzroku. Dzieci z uszkodzonym wzrokiem, tak jak osoby pełnosprawne, posiadają indywidualne cechy, które są biologicznie uwarunkowane (Majewski 1997, s. 32). Dlatego też w grupie tej znajdują się dzieci o różnych temperamentach, wrażliwości emocjonalnej, charakteryzujące się szybszym lub wolniejszym tempem uczenia się, sprawiające bądź nie różnego typu trudności wychowawcze. Niemniej jednak niewłaściwie pojęta normalizacja ukierunkowana na adaptację i pomijająca emancypację wychowanka z niepełnosprawnością może być działaniem szkodliwym, ponieważ niespełnienie wymogu przystosowania się do zasad ludzi pełnosprawnych „[...] musiałoby oznaczać zaliczenie sporej liczby osób niepełnosprawnych do kategorii ludzi »niewychowalnych"” (Krause 2011, s. 88).

Innych wyjaśnień dla zaobserwowanych trudności wychowawczych uczniów $\mathrm{z}$ niepełnosprawnością wzroku upatrywać można $\mathrm{w}$ sprzecznym $\mathrm{z}$ tradycyjnie rozumianym wychowaniem instrumentalizmie rewalidacyjnym - dążeniem do maksymalnego usprawniania i kompensacji deficytów rozwojowych dziecka. W sytuacji, kiedy procesy rehabilitacji (medycznej, psychologicznej i społecznej) stanowią centralny system oddziaływań na uczniów z niepełnosprawnością, wychowanie i kształcenie mogą zejść na drugi plan. W kontekście tego typu „instrumentalizmu rewalidacyjnego” (Krause 2011, s. 90) trudności wychowawcze mogą być błędnie rozumiane jako niepoddające się korekcji zachowania związane z deficytami rozwojowymi, których wyrównanie czy likwidację osiągnąć można 
raczej dzięki oddziaływaniom rehabilitacyjnym, a nie wychowawczym. Do takiej sytuacji dochodzi w placówkach, w których niepełnosprawność rozumiana jest w kategoriach modelu medycznego. Mimo że koncepcyjne podwaliny integracji, a tym bardziej inkluzji, opierają się na modelu społecznym niepełnosprawności, nie oznacza to, że ryzyko instrumentalizmu rewalidacyjnego nie grozi szkołom integracyjnym czy ogólnodostępnym. Doskonale tę sytuację pokazuje podział integracji na rehabilitacyjną i uspołeczniającą dokonany przez Zenona Gajdzicę na podstawie doświadczeń nauczycieli ze szkół integracyjnych (Gajdzica 2013). Koncepcja integracji rehabilitacyjnej zakorzeniona jest w filozofii medycznego modelu niepełnosprawności, w diagnozie nozologicznej i funkcjonalności organizmu. Ujawnia się w koncentracji na działaniach rehabilitacyjnych i czynnościach ukierunkowanych na realizację celów rehabilitacyjnych. W efekcie podmiotowość ucznia z niepełnosprawnością jest zredukowana, a jego życie zorganizowane według procesów korygowania i usprawniania (Krause 2011, s. 151). Z kolei integracja uspołeczniająca opiera się na relacjach w grupie, dobrym samopoczuciu dziecka i jego rozwoju. Ściśle wiąże się ze społecznym modelem niepełnosprawności, w którym decydującą rolę $\mathrm{w}$ formowaniu tego pojęcia odgrywają zewnętrzne ograniczenia. Rehabilitacja pełni funkcję służebną wobec edukacji i stanowi jej kontekst. Celem tych działań jest możliwie najpełniejsza socjalizacja i nawiązywanie symetrycznych relacji w grupie rówieśniczej. Od tego, jaki profil integracji przyjmuje dana placówka, zależeć może charakter socjalizacji ucznia z niepełnosprawnością, co ściśle łączy się także z definiowaniem trudności wychowawczych.

Kolejne wyjaśnienie występowania trudności wychowawczych wśród uczniów z niepełnosprawnością wzroku wyrasta z odniesień niespecyficznych, dotyczących wszystkich dzieci - konfiguracji egzo- i endogennych uwarunkowań zachowań trudnych. W tym rozumieniu niepełnosprawność ucznia może, ale nie musi przyczyniać się do ich występowania, raczej liczy się całokształt doświadczeń indywidualnych, rodzinnych i szkolnych. Przyczyny trudności wychowawczych można więc podzielić na endogenne - tkwiące $\mathrm{w}$ dziecku i ściśle połączone $\mathrm{z}$ działaniem czynników biopsychicznych oraz egzogenne - wynikające z oddziaływania środowiska, w jakim funkcjonuje dziecko (Łobocki 1989, s. 37). Jeśli szkoła przez swoje oddziaływania nie przyczynia się do powstawania trudności wychowawczych, ich źródeł należałoby poszukiwać w pewnych cechach temperamentu dziecka lub błędach wychowawczych rodziców. Biorąc pod uwagę jedynie pozaszkolne uwarunkowania, trudności wychowawcze można definiować jako niepoddające się zabiegom wychowawczym zachowania wynikające z niekorzystnej sytuacji biopsychicznej lub rodzinnej. W tym rozumieniu szkoła jest jedynie terenem manifestowania objawów zaburzeń już istniejących. 
Dużo bardziej skomplikowana jest sytuacja, w której zachowanie jest determinowane nie tylko wewnętrznymi cechami dziecka, ale także problemami wychowawczymi i społecznymi wynikającymi z działalności nauczyciela i szkoły. Barbara Grzyb (2013, s. 62) zaznacza nawet, że od sytuacji, w których szkoła jest jedynie terenem ujawniania się problemów wychowawczych, należy oddzielić te, w których to właśnie szkoła rzeczywiście staje się pierwotną przyczyną zaburzeń. Źródłem zachowań trudnych uczniów z niepełnosprawnością wzroku mogą być wówczas oddziaływania środowiska szkolnego, takie jak omawiane wyżej negatywne postawy ze strony rówieśników, procesy stygmatyzacji czy też niekorzystna sytuacja porównawcza (Por. Szumski 2010, s. 144). Nietrudno zauważyć, że prawdopodobieństwo zaistnienia wymienionych sytuacji jest wyższe w placówkach oferujących formy wspólnej edukacji dzieci z niepełnosprawnościami z pełnosprawnymi, czyli szkołach ogólnodostępnych i integracyjnych, niż w specjalnych.

\section{PODSUMOWANIE}

Przeprowadzone badania empiryczne pokazały, że częściej problemy związane z zachowaniem uczniów z niepełnosprawnością wzroku sygnalizują nauczyciele pracujący w szkołach integracyjnych i ogólnodostępnych niż pedagodzy ze szkół specjalnych. Taka sytuacja znajduje wiele wyjaśnień w ogólnych teoriach i dyskursach na temat wychowania w pedagogice specjalnej, które uważane jest za kategorię zaniedbywaną. Dokładna analiza charakteru ujawnianych trudności wychowawczych pozwala zauważyć, że część z tych zachowań utożsamiać można mniej z trudnościami, a bardziej zaś z normalnymi reakcjami dziecka o takim typie niepełnosprawności. Co więcej, większość wspomnianych problemów wydaje się możliwa do przezwyciężenia nie tyle dzięki zastosowaniu standardowych metod i programów profilaktyki, ile raczej dzięki samej świadomości ich źródeł. W sytuacji, kiedy identyfikuje się najwięcej trudności w szkołach integracyjnych i ogólnodostępnych, należy mieć na uwadze następujące możliwe przyczyny ich powstawania lub dostrzegania: tolerancję nauczycieli na odmienność zachowań ucznia, hierarchię celów wychowawczych, edukacyjnych i rehabilitacyjnych, konfigurację czynników rodzinnych i środowiskowych, w tym szczególnie szkolnych, które to szkoła powinna starannie diagnozować. Jeśli tak nie jest, bez odpowiedzi pozostaje pytanie, czy mamy do czynienia z trudnościami wychowawczymi uczniów, czy być może raczej z trudnościami w realizowaniu zadań wychowawczych szkoły. 


\section{LITERATURA}

Chłodna I., 2008, Edukacja amerykańska. Drogi i bezdroża. Lublin, Wydawnictwo KUL.

Czerwińska K., 2007, Stereotypy i uprzedzenia wobec osób niewidomych i słabo widzacych przegląd badań. „Wychowanie na co dzień”, 7/8.

Dykcik W., 2001, Wprowadzenie w przedmiot pedagogiki specjalnej. W: W. Dykcik (red.), Pedagogika specjalna, Poznań, Wydawnictwo UAM.

Gajdzica Z., 2013, Kategorie sukcesów w opiniach nauczycieli klas integracyjnych jako przyczynek do poszukiwania koncepcji edukacji integracyjnej. Kraków-Katowice, Oficyna Wydawnicza Impuls.

Gajdzica Z., 2015, O wychowaniu, którego zabrakło - kilka uwag na marginesie badań nad kształceniem integracyjnym i inkluzyjnym. „Annales UMCS”. Sectio J, vol. XXVIII, 1.

Grzyb B, 2013, Uwarunkowania związane z przenoszeniem uczniów niepełnosprawnych ze szkół integracyjnych do specjalnych. Kraków, Oficyna Wydawnicza Impuls.

Krause A., 2011, Współczesne paradygmaty pedagogiki specjalnej. Kraków, Oficyna Wydawnicza Impuls.

Łobocki M., 1989, Trudności wychowawcze w szkole. Warszawa, Wydawnictwo WSiP.

Majewski T., 1983, Psychologia niewidomych i niedowidzących. Warszawa, PWN.

Majewski T., 1997, Poradnik metodyczny dla nauczycieli pracujacych z dziećmi z uszkodzonym wzrokiem w systemie integracyjnym. Warszawa, PWZN.

Oleś P., Steuden S., Toczołowski J., 2002, Jak świata mniej widzę: zaburzenia widzenia a jakość życia. Lublin, Towarzystwo Naukowe KUL.

Osik D., 1991, Kształcenie uczniów niedowidzących w systemie integracyjnym w opinii nauczycieli. „Szkoła Specjalna”, 5.

Oświata i wychowanie w roku szkolnym 2013/2014, Warszawa, GUS.

Palak Z., 2000, Uczniowie niewidomi i słabowidzący w szkołach ogólnodostępnych. Lublin, Wydawnictwo UMCS.

Rozporządzenie Ministra Edukacji Narodowej z dnia 27 sierpnia 2012 r. w Sprawie podstawy programowej wychowania przedszkolnego oraz kształcenia ogólnego w poszczególnych typach szkół. Załącznik 2. (Dz.U. 2009 nr 4, poz. 17).

Sękowska Z., 1985, Pedagogika specjalna. Zarys. Warszawa, PWN.

Sękowska Z., 1998, Wprowadzenie do pedagogiki specjalnej. Warszawa, Wyższa

Szkoła Pedagogiki Specjalnej im. Marii Grzegorzewskiej.

Siwecka E., 2009, Stan i uwarunkowania trudności wychowawczych w gimnazjum. „Hejnał Oświatowy”, 11/87. 
Szumski G., 2010, Wokół edukacji włączającej. Efekty kształcenia uczniów z niepelnosprawnościq intelektualna $w$ stopniu lekkim $w$ klasach specjalnych, integracyjnych i ogólnodostępnych. Warszawa, Wydawnictwa Akademii Pedagogiki Specjalnej im. Marii Grzegorzewskiej.

\title{
BEHAVIOUR ISSUES AMONG STUDENTS WITH VISUAL IMPAIRMENT IN GENERAL, INTEGRATED AND SPECIAL SCHOOLS
}

\begin{abstract}
The article presents the problem of behaviour issues among students with visual impairment from the perspective of teachers working in inclusive, integrated and special schools. The theoretical part addresses the current problems of education in special pedagogy and describes blind and visually impaired students' behaviour issues which have been scientifically analysed. The empirical part is the analysis of teachers' views on the educational problems of students with visual impairment that are categorized according to the typology of Norbert Havers. In the last part, there is an attempt to explain an increased prevalence of educational problems among the group of pupils in inclusive and integrated schools compared to children from special schools. There are three spheres of explanation: the imbalance between adaptation and emancipation in the educational process, rehabilitating instrumentalism, endogenous and exogenous determinants of educational problems.
\end{abstract}

Key words: behaviour issues, educational problems, visual impairment, integration, inclusion 